\title{
Nuclear Magnetic Resonance Spectroscopy of Serum Albumin in First Episode Drug-Naïve Schizophrenic Patients
}

\author{
Uzbekov $\mathbf{M}^{* 1}$, Babushkina $T^{2}$, Klimova $T^{2}$, Peregudov $A^{2}$, Syrejshchikova $T^{3}$, Smolina ${ }^{1}{ }^{1}$, Brilliantova $V^{1}$, \\ Dobretsov $G^{4}$ and Shikhov $\mathbf{S}^{1}$ \\ ${ }^{1}$ Professor, Moscow Research Institute of Psychiatry, Russia \\ ${ }^{2}$ Senior Researcher, A N Nesmeyanov Institute of Elementoorganic Compounds, Russia
}

${ }^{3}$ Senior Researcher, Lebedev Physical Institute, Russia

${ }^{4}$ Professor, Research and Clinical Center of Physic-Chemical Medicine, Russia

*Corresponding author: Uzbekov MG, Laboratory of Brain Pathology, Moscow Research Institute of Psychiatry, Moscow, Russia

ARTICLE INFO

Received: 幽 February 07, 2019

Published: 蔧 March 01, 2019

Citation: Uzbekov M, Babushkina T, Klimova T, Peregudov A, Syrejshchikova T, et al. Nuclear Magnetic Resonance Spectroscopy of Serum Albumin in First Episode Drug-Naïve Schizophrenic Patients. Biomed J Sci \& Tech Res 15(3)-2019. BJSTR. MS.ID.002695.
ABSTRACT

Background: Changes of albumin conformation and its binding centers can be one of earlier unknown before and very important factors of the pathogenesis of condition. Normal albumin functioning has to be tightly connected with the normal conformation of the protein.

Aim: The aim of the study was to reveal both conformational changes of albumin molecule and changes of different metabolites in biological fluids in first episode drug-naïve schizophrenic (FES) patients.

Method: 19 FES patients were investigated before any antipsychotic therapy. High resolution nuclear magnetic resonance ${ }^{1} \mathrm{H}$ (HRNMR $\left.{ }^{1} \mathrm{H}\right)$ spectroscopy in strong magnetic field was used.

Results and Conclusion: There was observed both the increase of the number of fatty acid molecules, connected with albumin and the increase of the motility of fatty acid methyl-groups in FES patients. HRNMR ${ }^{1} \mathrm{H}$ spectra of blood serum of FES patients point out on the changes in the ratio between different lipid fractions, connected with albumin whereas NRNMR ${ }^{1} \mathrm{H}$ spectra of albumin, isolated from serum, points out on the different ligand loading of albumin of FES patients and healthy controls; the latter can be considered as conformational disturbances of albumin molecule.

\section{Introduction}

It becomes clear that the development of the pathological process can be followed by the conformational disturbances of the proteins, i.e. the orientation of a protein molecule in the space. For example, conformational disturbances of prion proteins lead to mental disorders [1]. Earlier we have shown that schizophrenia and depression are followed by changes of conformation and consequently by disturbances of physic-chemical properties of albumin [2].

Albumin is the main determinant protein of plasma and it plays a pivotal role in many metabolic processes. It has many biological properties such as capacity of molecule transportation and free radical scavenging, its ability to modulate capillar permeability, neutrophil adhesion and activation and its haemostatic effects which may be important not only for its physiological functions but also for its therapeutic effects.

Changes of albumin conformation and its binding centers can be one of earlier unknown before and very important factors of the pathogenesis of condition. Normal albumin functioning has to be tightly connected with the normal conformation of the protein: active groups of the molecule (amino-groups, thiol-groups, 
binding centers) have to be accessible for the interaction with ligands (different metabolites and drugs), i.e. has to have a "native" conformation [3].

Managing patients with first episode of schizophrenia (FES) is a complicated task for psychiatrists. Early diagnosis and effective interventions are vital to achieving long-term positive outcomes among such kind of patients. It seems to be generally accepted that patients suffering from a FES tend to be more responsive to antipsychotic treatment than multiple-episode patients. Prompt and efficient treatment of acute psychotic episode combined with the prevention of relapses will limit the increased morbidity of schizophrenia and will increase the level of patient's social functioning and the quality of life [4].

Earlier we have revealed conformational changes in albumin molecule of FES patients using subnanosecond laser fluorescent spectroscopy [5]. High resolution nuclear magnetic resonance ${ }^{1} \mathrm{H}$ (HRNMR ${ }^{1} \mathrm{H}$ ) spectroscopy in strong magnetic field gives the possibility to show both conformational changes of albumin molecule and also changes of different metabolites in biological fluids in this pathological condition. That was the aim of this investigation.

\section{Subjects and Methods}

There were investigated 19 first episode drug-naïve schizophrenic patients before any antipsychotic therapy. There was diagnosed in all cases paranoid schizophrenia (F20.0) according to ICD-10 criteria. The control group consisted of 6 volunteers who according to the clinical-biochemical parameters were healthy individuals and were comparable demographically and age-wise with the FES patients. Investigation was performed in accordance of Helsinki Declaration and on conclusion of the local ethical committee of the Institute (N 43/2 of 27/04/2009).
High resolution nuclear magnetic resonance ${ }^{1} \mathrm{H}$ (HRNMR $\left.{ }^{1} \mathrm{H}\right)$ spectroscopy in strong magnetic field of blood serum and albumin fraction, isolated from serum, were measured on Avance-600 (Bruckr USA) according to [6,7]. Serum concentration calculated by serum albumin was $50 \mathrm{mg} / \mathrm{ml}$; albumin fraction concentration in water solurion was $25 \mathrm{mg} / \mathrm{ml}$.

\section{Results and Discussion}

NRNMR ${ }^{1} \mathrm{H}$ spectra of blood serum and its albumin fraction of healthy donors and FES patients were studied. There were shown clear differences in NRNMR ${ }^{1} \mathrm{H}$ spectra between these two groups. There was detected amplification of intensity $\mathrm{CH}_{2}$ proton lipid signals in blood serum. It points out on increase of long chain lipids concentration and relative changes of low-density lipid fraction in serum of FES patients in comparison with controls. At the same time there was observed amplification of intensity of methyl protons signals of non-esterified fatty acids in albumin water solution spectra of albumin molecule of FES patients. It is quite likely that amplification of intensity of $\mathrm{CH}_{2}$ proton signal is connected with the increase of quantity long-chain lipids fraction in FES patients.

For additional information we have investigated the NRNMR $1 \mathrm{H}$ spectra of albumin fraction, isolated from serum, of FES patients and controls (Figure 1). The protein isolation procedure in that case yields protein complexes with stably bound ligands. It was observed that intensity of $\mathrm{CH}_{2}$ and $\mathrm{CH}_{3}$ protons lipid signals sharply increased in FES patients. It points out both on the increase of the number of fatty acid molecules, connected with albumin and on the increase of the motility of fatty acid methyl-groups in FES patients. The mean ratio of relative integral intensity of the total wide signal of fatty acid and $\mathrm{Lac}_{2} \mathrm{CH}_{2}$ protons to the relative intensity of Ala signal differed significantly and was $6.72 \pm 1.11$ and $3.9 \pm 0.32$ for FES patients and controls, respectively $(\mathrm{p}=0.01)$.



Figure 1: High resolution nuclear magnetic resonance ${ }^{1} \mathrm{H}$ spectra of albumin fraction, isolated from serum, of healthy controls (above) and FES patients (below), where ЖK - is fatty acid, lac - lactate, ala - alanine. 


\section{Conclusion}

High resolution nuclear magnetic resonance ${ }^{1} \mathrm{H}$ spectra of blood serum of FES patients point out on the changes in the ratio between different lipid fractions, connected with albumin whereas NRNMR ${ }^{1} \mathrm{H}$ spectra of albumin, isolated from serum, points out on the different ligand loading of albumin of FES patients and healthy controls. These results support our hypothesis about conformational changes of albumin molecule and disturbances in albumin transport functions in first episode of schizophrenia.

\section{References}

1. Prusiner SB (1998) Prions. Proc Natl Acad Sci 95(23): 13363-13383.

2. Uzbekov MG, Syrejshchikova TI, Babushkina TA, Smolina NV, Kalinina VV, et al. (2013) High-tech approaches promote to recognize conformational changes in albumin molecule in first episode drug-naïve schizophrenic patients. Siberian Gerald of Psychiatry and Narcology 1: 26-30.

\section{ISSN: 2574-1241}

DOI: 10.26717/BJSTR.2019.15.002695

Uzbekov MG. Biomed J Sci \& Tech Res

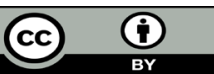

This work is licensed under Creative Commons Attribution 4.0 License

Submission Link: https://biomedres.us/submit-manuscript.php
3. Syrejshchikova TI, Smolina NV, Brilliantova VV, Uzbekov MG, Dobretsov GE (2017) Albumin Binding-Site Alteration in Melancholic Depression under Pharmacotherapy: Recording with the Use of Subnanosecond Fluorescence Spectroscopy. Biophysics 62(2): 286-290.

4. Uzbekov MG, Misionzhnik EY, Gurovich IY, Shmukler AB (2013) Aspects of metabolic changes in first-episode drug-naïve schizophrenic patients. Acta Neuropsychiatrica 25(5): 268-274.

5. Uzbekov M, Syrejshchikova T, Babushkina T, Smolina N, Kalinina V, et al. (2015) First episode of schizophrenia is followed by conformational and functional disturbances of serum albumin. Europ Arch \& Psychiatry and Clin Neurosci 265(Suppl1): S94.

6. Engan T, Krane J, Kvinnaland S (1991) Proton nuclear magnetic resonance spectroscopy measurements of methylene and methyl line widths in plasma: Significant variations of breast cancer, duration of pregnancy and aging. NMR Biomed 4(3): 142-149.

7. Vasileva A, Jakob M, Hasko F (1981) Application of ion-exchange chromatography for the production of human albumin. J Chromatogr 216: $279-284$

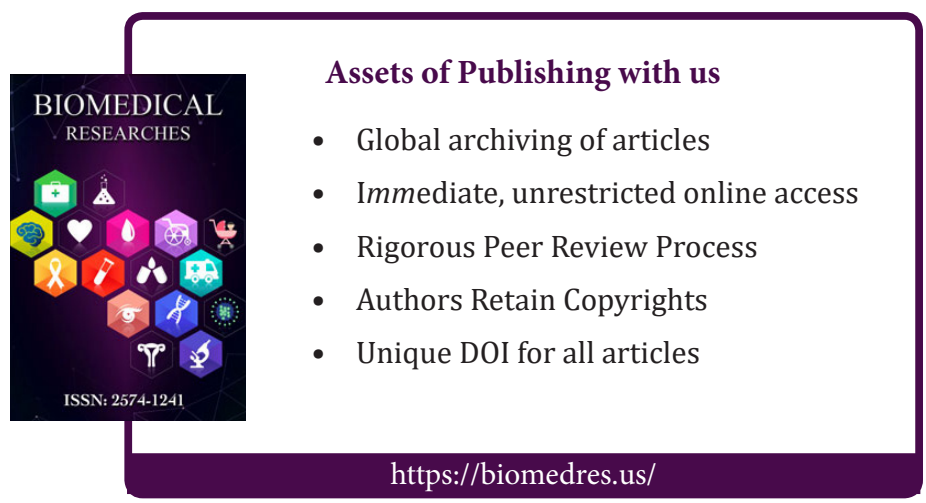

